\title{
MATERIAEY
}

Justyna Gulczyńska

(Poznañ)

\section{Kontrowersje wokół struktury ustrojowo-organizacyjnej i programowej szkolnictwa średniego ogólnokształcącego w Polsce w latach 1944-1948}

\section{Nowy ustrój państwa polskiego i jego wpływ na charakter szkolnictwa średniego ogólnokształcącego}

Pierwszy okres istnienia Polski Ludowej to czas, w którym w zakresie organizacji i zarządzania oświatą zauważyć można tendencje zmierzające w kierunku centralizacji tego zagadnienia. Wszystkie sprawy związane $\mathrm{z}$ oświatą $\mathrm{i}$ wychowaniem oraz wszystkie działy systemu szkolnego znalazły się w gestii ministra oświaty, nie podlegały mu tylko sprawy wyznań religijnych i kultury. Utrzymano wprawdzie terenowe władze oświatowe: kuratoria okręgów szkolnych w województwach oraz inspektoraty szkolne w powiatach, ale zarówno kuratoria, jak i inspektoraty podlegały bezpośrednio ministrowi oświaty ${ }^{1}$. Ten centralizm w polityce oświatowej państwa polskiego miał charakter dość stonowany. $\mathrm{W}$ porównaniu $\mathrm{z}$ okresem następnym, był on raczej ewolucją $\mathrm{w}$ kierunku intensyfikacji systemu komunistycznego, by w następnych latach, po roku 1948, przybrać postać wręcz rewolucyjną.

Postulowany tzw. proces demokratyzacji szkoły, został określony już w deklaracji programowej PPR w listopadzie 1943 r. pt. „O co walczymy?”. Napisane jest w nim m.in.: „Szkoła i organizacja szkolnictwa od szczebli najniższych do najwyższych, oparta na zasadach demokracji, musi być tak postawiona, aby zapewniła możność bezpłatnego kształcenia się młodzieży robotniczej i chłopskiej na wszystkich szczeblach nauki. Powszechne i obowiązkowe nauczanie powinno obejmować całą młodzież do lat 16. Ponieważ zasób wiedzy jest dobrem ogólnonarodowym, państwo zabezpiecza niezamożnej a zdolnej młodzieży możność studiów w wyższych uczelniach przez wypłacanie dostatecznych stypendiów"2. Również Manifest Polskiego Komitetu Wyzwolenia Narodowego głosił, że „Jednym z najpilniejszych zadań Polskiego Komitetu Wyzwolenia Narodowego

\footnotetext{
${ }^{1}$ M. Pęcherski, M. Swiątek, Organizacja oświaty w Polsce w latach 1917-1969. Podstawowe akty prawne, Warszawa 1972.

${ }^{2}$ Wydział Historii Partii KC PZPR: W dziesiątą rocznicę powstania Polskiej Partii Robotniczej. Materiały i dokumenty, Warszawa 1952, s. 193, (za:) M. Maciaszek, Treść kształcenia $i$ wychowania $w$ reformach szkolnych PRL, Warszawa 1980
} 
będzie na terenach oswobodzonych odbudowa szkolnictwa i zapewnienie bezpłatnego nauczania na wszystkich szczeblach. Polska inteligencja zdziesiątkowana przez Niemców, a zwłaszcza ludzie nauki i sztuki, zostaną otoczeni specjalną opieką"3.

W okresie po Oświatowym Zjeździe Łódzkim, który miał miejsce w dniach 18-22 czerwca 1945 r., w środowiskach nauczycielskich oczekiwano istotnych zmian w systemie szkolnictwa polskiego, które miały się dokonać zgodnie z przyjętymi ustaleniami zjazdowymi. Polityka oświatowa jednak nie podjęła realizacji postanowień Zjazdu. Nie znalazły one należytego miejsca w "Instrukcji o organizacji roku szkolnego 1945/46"4.

Ten brak spójnego stanowiska w polityce oświatowej Ministerstwa po Zjeździe ożywił spory i kontrowersje na temat modelu szkolnego. Terenem wielu polemik stały się stronnictwa polityczne ${ }^{5}$ oraz dyskusje na temat reformy oświaty, towarzyszące kolejnym spotkaniom, konferencjom, zjazdom.

Głównym stronnictwem politycznym, które starało się realizować decydującą politykę oświatową w Polsce powojennej, była oczywiście Polska Partia Robotnicza. Określała ona swój program, ale w $1945 \mathrm{r}$. nie pozwalała sobie na jego pełną realizację, próbując wprowadzić w życie te elementy, które akceptowali nie tylko komuniści. Działo się tak, ponieważ wpływ na szkolnictwo ograniczał koalicyjny charakter rządu i osoba ministra Czesława Wycecha, pochodzącego z Polskiego Stronnictwa Ludowego.

Całościowy program szkolny powstał w maju 1945 r. jako podsumowanie krajowej narady nauczycieli członków PPR. Przyjęto wówczas sześć tez programowych:

1) oparcie ustroju szkolnego na zasadach jednolitości, powszechności, państwowości, bezpłatności nauczania;

2) wyznaczenie dolnej granicy obowiązku szkolnego na siódmy rok życia;

3) rozciągnięcie przymusu szkolnego na osiem lat;

4) oparcie edukacji młodzieży na dwóch typach szkół: 8-letniej podstawowej oraz trzyletniej średniej (licealnej lub zawodowej);

5) rozbudowa szkolnictwa zawodowego;

6) realizacja hasła: ani jednego dziecka w wieku szkolnym poza murami szkoły ${ }^{6}$.

Dość szybko okazało się, że program jest nierealny. Przede wszystkim dlatego, że władze oświatowe nie były w stanie stworzyć szkół ośmioletnich ze względu na brak budynków i nauczycieli. Poza tym całkowite pominięcie w tezach istniejących dotychczas szkół średnich gimnazjalnych komplikowało rzetelną ocenę faktów, a przecież szkoły te kształciły elity i w nich pracowali najlepsi nauczyciele. Ponadto powstanie 3-letnich szkół zawodowych okazało się, przynajmniej w pierwszych latach Polski Ludowej, zadaniem zbyt trudnym ze względu na niechęć zdolniejszych uczniów do tego typu szkół oraz trudności materialne państwa. Niemniej, lekceważenie szkół średnich gimnazjalnych świadczące o niechęci komunistów do nich, a troska o szkoły zawodowe były ważnymi

\footnotetext{
${ }^{3}$ Manifest Polskiego Komitetu Wyzwolenia Narodowego, Dz. Urz. Resortu Oświaty 1944/Nr 1.

${ }^{4}$ Instrukcja $\mathrm{z}$ dnia 16 lipca 1945 roku w sprawie organizacji roku szkolnego 1945/46 w średnich szkołach ogólnokształcących, Dz. Urz. Min. Ośw. 1945/Nr2/poz. 62.

${ }^{5}$ S. Mauersberg, Reforma szkolnictwa w Polsce w latach 1944-1948, s. 107-113.

${ }^{6}$ AAN PPR, 295/X/19, k. 11a, (za:) K. Kosiński, O nowq mentalność. Życie codzienne $w$ szkołach 1945-1956, Warszawa 2000, s. 37-38.
} 
sygnałami w ówczesnej polityce oświatowej, sygnałami, które powróciły w latach późniejszych, przybierając postać rewolucyjną ${ }^{7}$.

W dniach 7-8 października 1945 r. obradowała w Warszawie II Konferencja nauczycieli członków PPR, podczas której zauważyć można, jak wiele znaczyło dla władzy ludowej szkolnictwo i ile uwagi jemu poświęcano. Stwierdzono na niej, że ZNP, który w okresie istnienia PKWN i Rządu Tymczasowego głosił politykę neutralności, zaczął działać pod wpływem Mikołajczyka i PSL-u. Również Polska Partia Socjalistyczna miała dość znaczne poparcie wśród nauczycieli, natomiast wpływy PPR były poważnie ograniczone $^{8}$. W końcowych rezolucjach Konferencji wezwano rząd do opracowania i wprowadzenia w życie nowej ustawy szkolnej przewidującej 8-letnie obowiązkowe szkoły podstawowe oraz obowiązkowe dokształcanie młodzieży do 18 roku życia. Wzywano też do przyśpieszenia i zakończenia prac nad programami szkolnymi, opartymi na naukowym poglądzie na świat i zgodnymi z postępową tradycją demokracji polskiej".

Inne stanowisko na temat odbudowy szkolnictwa i reformy szkolnej zajęli nauczyciele PPS podczas ogólnopolskiego zjazdu, który odbył się w Warszawie w dniach 16-17 listopada 1945 r. Domagali się oni niezależnej, świeckiej, bezpłatnej, jednolitej i obowiązkowej szkoły dla wszystkich dzieci. Nauczyciele ci, w obecności premiera Edwarda Osóbki-Morawskiego, postulowali 10-klasowe gimnazjum powszechne, którego autorem był głównie przewodniczący zjazdu - Teofil Wojeński. W deklaracji ideowej przyjętej przez zjazd nauczyciele - członkowie PPS domagali się wysunięcia w budżecie państwa potrzeb oświatowych na plan pierwszy ${ }^{10}$.

Sytuacja, w której urzędnicy państwowi - pracownicy Ministerstwa Oświaty, działacze związkowi i oświatowi - reprezentowali stanowiska różnych stronnictw i partii politycznych na sprawy oświatowe powodowała, że postawa wewnątrz Ministerstwa była niestabilna i bardzo różnorodna. Minister Cz. Wycech, dyrektor W. Schayer, prezes ZG ZNP - K. Maj byli jako działacze oświatowi „Rocha” i TON twórcami i orędownikami ludowych i nauczycielskich koncepcji oświatowych z czasów okupacji. Związek ten trwał nadal w czasach Polski Ludowej, a ponieważ TON i „Roch” działały podczas okupacji pod wpływem sił politycznych powiązanych $\mathrm{z}$ emigracją londyńską, oświatowi działacze „Rocha” wstąpili do PSL, na którego czele stanął były premier rządu emigracyjnego Stanisław Mikołajczyk ${ }^{11}$. PSL nieprzejawiające więc zgodności poglądów z partiami robotniczymi, w swej polityce oświatowej było ostro krytykowane przez działaczy PPR.

Podczas Kongresu PSL, który odbył się w Warszawie w dniach 19-21 stycznia 1946 r., miała miejsce wypowiedź na temat konieczności „szybkiego wkroczenia na drogę realizaçji idei powszechnego kształcenia młodzieży na poziomie średnim od czasu ukończenia szkoły powszechnej do lat $18^{\prime \prime 12}$. Zdaniem zjazdowców upowszechnienie szkoły średniej miało odbywać się różnymi drogami, ale przede wszystkim postulowano upowszechnienie szkół na wsi.

\footnotetext{
${ }^{7}$ Tbidem, s. 38.

${ }^{8}$ S. Mauersberg, op.cit., s.107

${ }^{9}$ Ibidem, s. 107

${ }^{10} \mathrm{Ibidem}, \mathrm{s.} 108$

${ }^{11}$ Ibidem, s.109

${ }^{12}$ AZHRL, Kongres PSL, II PSL - 37, s. 128, (za:) S. Mauersberg, op.cit, s. 109.
} 
Uchwały oświatowe Kongresu PSL oraz wypowiedzi ministra Wycecha, który kierował podczas Kongresu pracami Komisji Oświatowej, znalazły się pod silną presją peperowskich działaczy oświatowych, tym bardziej, że Ministerstwem kierował wówczas wicepremier Stanisław Mikołajczyk.

W dniach 23-24 marca 1946 r. w Warszawie miała miejsce Konferencja, podczas której doszło do uzgodnienia poglądów w sprawie reformy szkolnej nauczycieli PPS i PPR. W rezolucji końcowej zamieszczono uchwały, które mówią o konieczności przeciwstawienia się zarówno przez PPR, jak i PPS wszelkim próbom zahamowania realizacji rozpoczętej reformy szkolnej. Zwrócono uwagę na konieczność uruchomienia w kolejnym roku szkolnym 8-klasowej szkoły państwowej oraz likwidację I klasy gimnazjalnej, a także rozpoczęcie prac nad rozbudową przyszłej szkoły średniej opartej na 8-klasowej szkole państwowej. Konferencja wypowiedziała się za likwidacją klas wstępnych, które ich zdaniem były zamaskowaną formą klasy pierwszej gimnazjum, a tym samym zaprzeczały zasadzie jednolitości szkoły ${ }^{13}$.

Sprawą realizacji reformy szkolnej zajęto się również podczas I Kongresu Stronnictwa Demokratycznego, który odbył się w lipcu 1946 r. Tutaj decydującym było wystąpienie Eugenii Krassowskiej, która zarzucała Ministerstwu ograniczanie możliwości podnoszenia stopnia organizacyjnego szkół tak miejskich, jak i wiejskich. I Krassowska, jak i całe Stronnictwo Demokratyczne było za jak najszybszą realizacją wysoko zorganizowanej szkoły. Pod wpływem referatu Krassowskiej oraz na wniosek Komisji Kulturalno-Oświatowej, Kongres wezwał rząd do niezwłocznego przystąpienia do wprowadzenia pełnych szkół 8-klasowych, a od 1 września 1946 r. zaniechał tworzenia klas wstępnych w gimnazjum. Ponadto postulowano, aby wszystkie sprawy oświatowe skupione były $w$ jednym resorcie. Kongres żądał też stanowiska ministra lub wiceministra oświaty, co przełożyło się na powołanie Eugenii Krassowskiej na stanowisko podsekretarza stanu w Ministerstwie Oświaty ${ }^{14}$.

Zakres i tempo realizowanej przez Ministerstwo Oświaty reformy szkolnej nadal były ostro krytykowane przez lewicę nauczycielską, lecz w końcu roku 1946 głównym ogniskiem tej krytyki stała się PPS, natomiast aktyw oświatowy PPR wypowiadał się na ten temat coraz bardziej powściągliwie i ostrożnie ${ }^{15}$.

Kongres oświatowy PPS, który odbył się 8-10 grudnia 1946 r. uznał dotychczasowy sposób realizacji reformy szkolnej za niewystarczający i zdecydowano się powtórzyć tezy wygłoszonego podczas poprzedniego, wspomnianego wyżej Kongresu, referatu kuratora warszawskiego, Teofila Wojeńskiego, który twierdził, że:

1) istota reformy szkolnej nie tkwi w dodaniu klasy do szkoły powszechnej, lecz w upowszechnieniu nauczania na poziomie średnim i w jednolitym ukierunkowaniu ideowym szkoły;

2) charakter i tempo reformy szkolnej muszą być dostosowane do charakteru i tempa przemian polityczno-społecznych;

\footnotetext{
${ }^{13}$ ZHP, Dział PPS, Wydział Oświaty i Kultury. Protokół z konferencji aktywu nauczycieli PPR i PPS w dniu 23 i 24 III 1946 w CKW PPS, 235/XVII - 6, s. 10, (za:) S. Mauersberg, op.cit., s. 112-113.

${ }^{14}$ Ibidem, s. 112 .

${ }^{15}$ Ibidem, s. 121 .
} 
3) reformę szkolną należy realizować wszędzie, gdzie są ku temu warunki, a nie tylko w niektórych regionach ${ }^{16}$.

Kongres, uznając dotychczas realizowaną reformę za niewystarczającą, wzywał do powtórzenia wyżej wymienionych tez, a także do współpracy ideowej nauczycieli z klasą robotniczą i ruchem chłopskim dla - jak pisano, utrwalenia zdobyczy demokracji i przebudowy postawy psychicznej narodu.

Dnia 19 stycznia 1947 r. miały miejsce wybory do Sejmu Ustawodawczego, które spowodowały wyraźne osłabienie wpływu PSL. Poza tym w łonie samego stronnictwa powstał rozłam i narastała opozycja wobec Stanisława Mikołajczyka i jego najbliższych współpracowników.

Już podczas pierwszej sesji Sejmu wyraźnie sygnalizowano nowy kierunek polityki oświatowej, podkreślając konieczność tzw. demokratyzacji wychowania, co oznaczało w praktyce nic innego, jak podjęcie zdecydowanej ofensywy ideologicznej w szkole.

Premier Józef Cyrankiewicz (PPS) przedstawiając w exposé z 19 czerwca 1947 r. osiągnięcia szkolnictwa polskiego, podkreślał jednocześnie, iż szczególną troską rządu jest demokratyzacja szkolnictwa i wychowywanie młodzieży w duchu demokracji ludowej i narodowej ${ }^{17}$.

Ministrem oświaty w rządzie Cyrankiewicza powtórnie został Stanisław Skrzeszewski (PPR). Poza tym dokonano istotnych zmian personalnych we władzach oświatowych. Z kierownictwa Ministerstwa Oświaty odeszli członkowie PSL. Odwołano wszystkich, tj. 5 kuratorów należących do PSL. Wśród 14 kuratorów -4 było członkami PPR, 4 - PPS, 3 - SL i 2 - SD. Na stanowiskach inspektorów i podinspektorów szkolnych dokonano 375 zmian $^{18}$. Zmiany te wskazują na zdecydowany zwrot $\mathrm{w}$ polityce oświatowej państwa.

Latem 1948 r. w kierownictwie KC PPR ujawniły się ostre różnice poglądów i stanowisk w koncepcji polskiej drogi do socjalizmu. Ze stanowiska sekretarza generalnego KC PPR usunięto Władysława Gomułkę i powołano na jego miejsce Bolesława Biureta. Nowe kierownictwo partyjne podjęło generalną ofensywę ideologiczną, również w aspekcie wychowawczo-edukacyjnym.

W dniu 30 października 1948 r. odbyła się w Warszawie krajowa narada aktywu oświatowego PPR, której celem było wytyczenie szkolnictwu zadań w warunkach toczącej się walki o ideologię, treść i metody nauczania. Poddano krytyce dotychczasową politykę oświatową, zarzucając jej opóźnienie przebudowy ideologicznej i organizacyjnej szkó $1^{19}$. Minister Skrzeszewski podczas wystąpienia skrytykował zbyt wolno dokonujące się zmiany w programach i podręcznikach, zaniedbanie szkoły wiejskiej, opieszałe reorganizowanie szkoły średniej. Do osiągnięć natomiast zaliczył dokonanie przebudowy strukturalnej szkoły podstawowej i średniej. Rezolucje końcowe narady dotyczyły m.in.

\footnotetext{
${ }^{16}$ Wychowanie nowego człowieka, Pierwszy dzień obrad Kongresu Oswiatowego PPS, „Robotnik”, nr 239 z dnia 9 XII 1946, (za:) S. Mauersberg, op.cit., s. 121.

${ }^{17}$ Sprawozdanie stenograficzne z posiedzeń Sejmu Ustawodawczego w dniu 8 lutego 1947, łam 34, (za:) S. Mauersberg, op.cit., s. 150, 181-182.

${ }^{18} \mathrm{Ibidem}, \mathrm{s} .182$.

${ }^{19}$ Ibidem, s. 234.
} 
szerszego udostępnienia szkół średnich, rewizji programów nauczania na wszystkich szczeblach, oparcia systemu wychowawczego na zasadach marksizmu-leninizmu oraz powiązania pracy wychowawczej z ideowymi organizacjami młodzieżowymi ${ }^{20}$.

Podobny klimat towarzyszył konferencji aktywu oświatowego, jaka odbyła się 15 listopada 1948 r. Krytykując dotychczasową politykę oświatową PPS, zalecano m.in. utworzenie jednolitego systemu organizacyjnego szkolnictwa, podnoszenie stopnia organizacyjnego szkół wiejskich, zwiększenie dopływu dzieci chłopskich i robotniczych do szkół średnich, dokonanie rewizji programów i podręczników, otoczenie młodzieży opieką ideologiczną, przebudowanie organizacyjne i programowe ZHP, upaństwowienie wszystkich szkót ${ }^{21}$. Ówczesny minister oświaty Henryk Jabłoński w referacie wygłoszonym podczas Konferencji stwierdził, że nie zostały dotychczas jasno sformułowane cele wychowawcze i światopoglądowe, a w programach i podręcznikach trafiały się treści tradycjonalistyczne i nacjonalistyczne ${ }^{22}$.

Warto dodać, że po dramatycznych wydarzeniach 1947 r. (porażka PSL w wyborach, rozłam wewnętrzny w partii, ucieczka S. Mikołajczyka), powstały dwie partie, tj. Stronnictwo Ludowe i Polskie Stronnictwo Ludowe. W maju 1948 r. stronnictwa te podpisały deklarację o współpracy i jedności działania; stanęły zatem na stanowisku sojuszu robotniczo-chłopskiego. W konsekwencji stronnictwa zwróciły się w stronę „budowy socjalizmu i wychowania internacjonalistycznego"23.

\section{Szkoły średnie ogólnoksztalcące państwowe i prywatne w Polsce powojennej w kontekście zmian ustrojowych}

Ograniczone możliwości budżetowe państwa polskiego po zakończeniu działań wojennych powodowały, że oprócz szkół średnich ogólnokształcących państwowych ${ }^{24}$ istniały w Polsce w stosunkowo dużej liczbie szkoły średnie ogólnokształcące prywatne ${ }^{25}$. 1 grudnia 1945 r. wśród 705 szkół średnich ogólnokształcących - 383 to szkoły państwo-

\footnotetext{
${ }^{20}$ Ibidem, s. 234-235.

${ }^{21}$ Ibidem, s. 236.

${ }^{22}$ H. Jabłoński, Polityka oświatowa w Polsce Ludowej, „Wiedza i Życie” 1948/Nr12/s.1050, (za:) S. Mauersberg, op.cit., s. 236.

${ }^{23}$ AZHRL, Stronnictwo Ludowe, SL/34, (za:) S. Mauersberg, op.cit., s. 238.

${ }^{24}$ Państwowość szkół średnich była priorytetem w otwieraniu tych placówek.

${ }^{25}$ Rozporządzenie Ministra W. R. i O. P. z dnia 5 lipca 1939 r. (Dz. Urz. M. W. R. i O. P./Nr7/poz.179) o organizacji państwowej szkoły średniej ogólnokształcącej (liceum i gimnazjum) przewidywało, że każda szkoła średnia ogólnokształcąca istnieć może na podstawie wydanego dla niej zarządzenia organizacyjnego. W pierwszych miesiącach po wyzwoleniu Polski, organizując szkolnictwo - uruchamiano szkołę średnią jako placówkę państwową, chociaż taką nie była przed 1939 r. - nie uzyskiwała orzeczenia Ministerstwa, lecz mimo to funkcjonowała. Również szkoły średnie ogólnokształcące istniejące przed wojną były placówkami albo męskimi, albo żeńskimi. Po wojnie przekształcono je w szkoły koedukacyjne. Często też zmieniano wydziały w liceum, zmieniano nazwę szkoły, np. jej patrona. Z czasem sytuacja ta uległa uporządkowaniu na podstawie wykazów nadesłanych do Ministerstwa przez poszczególne Kuratoria Okręgów Szkolnych (KOS), Ministerstwo Oswiaty, Departament Szkolnictwa Ogólnokształcącego. Sprawa zmiany organizacji państwowych szkół średnich ogólnokształcących, AAN, Zespół 283, sygn. 1575/2.
} 
we, natomiast 322 to szkoły niepaństwowe, przy czym w niektórych województwach (m.in. w warszawskim, krakowskim, lubelskim) liczba szkół niepaństwowych dwukrotnie przewyższała liczbę szkół państwowych ${ }^{26}$.

Ministerstwo Oświaty zgadzało się na istnienie szkół prywatnych ${ }^{27}$, ponieważ szkoły te odciążały budżet państwowy. Ze względów ideologicznych jednak poważne zastrzeżenia lewicy budziło istnienie szkół średnich prowadzonych przez zakony. Początkowo szkoły te tolerowano, aczkolwiek ich stan liczbowy zmalał zaraz po wojnie o połowę. Zakony prowadziły przed wojną 86 szkół średnich ogólnokształcących z liczbą 12,5 tysięcy uczniów, natomiast wiosną 1946 r. działały 44 takie szkoły, liczące 6,5 tysiąca dziewcząt i chłopców. W szkołach tych panował religijny kierunek wychowania, młodzież uczestniczyła w obowiązkowych praktykach religijnych oraz należała do Sodalicji Mariańskiej. Działalność ta niepokoiła posłów Stronnictwa Ludowego z Janem Rusinem na czele, którzy w kwietniu 1946 r. zarzucili Ministerstwu Oświaty, że oddaje oświatę w ręce zakonów. Ministerstwo natomiast w odpowiedzi na zarzuty, 12 czerwca wystosowało pismo skierowane do Prezydium KRN, w którym powołało się na podstawy prawne szkół zakonnych wynikające z Konstytucji marcowej oraz ustawy z 11 marca 1932 r. o prywatnych szkołach. Wyjaśniło ono, że stan szkolnictwa prowadzonego przez zakony zmalał po wojnie do połowy w stosunku do stanu przedwojennego ${ }^{28}$.

Tendencje malejące dla tych szkół istniały nadal, ponieważ w roku szkolnym 1947/48 istniały 42 szkoły średnie ogólnokształcące katolickie, liczące 8 tys. uczennic i uczniów, z których jedna trzecia mieszkała w internatach przyszkolnych.

Władze państwowe dość skutecznie nękały szkoły katolickie, chcąc ograniczać ich liczbę. Odbywało się to m.in. przez próby zakładania w tych szkołach organizacji antychrześcijańskich - Związku Walki Młodych czy Organizacji Młodzieży Towarzystwa Uniwersytetu Robotniczego, pełniących dywersyjną rolę wobec wychowania katolickiego. Ponadto obowiązywał kategoryczny zakaz tworzenia w szkołach młodzieżowych organizacji katolickich. Nakłaniano równieź rodziców do przenoszenia swych dzieci ze szkół katolickich do państwowych. Odbierano niektórym szkołom katolickim uprawnienia szkół państwowych, jeśli natomiast wydawano takie uprawnienia, to czyniono to $w$ ostatniej chwili i tylko na jeden rok szkolny, co wytwarzało wśród rodziców i uczniów atmosferę niepokoju i niepewności z trudem przezwyciężaną przez szykanowaną dyrekcję i nauczycieli ${ }^{29}$.

\footnotetext{
${ }^{26}$ Ministerstwo Oświaty. Szkolnictwo w liczbach 1945/46, s. 26, 39.

${ }^{27}$ W Zarządzeniu czytamy, że szkola taka zorganizowana powinna być na wzór państwowy. W załączniku do Zarządzenia, będącym drukiem do wypełnienia przez szkołę prywatną ubiegającą się o zgodę, jeden z punktów mówi o tym, że dyrekcja szkoły ma określic, w jakim stopniu szkoła spełnia zadania państwowe i społeczne. Zagadnienie to zdecydowanie wskazuje, jak bardzo ówczesnym władzom chodziło o pełną kontrolę nad szkolnictwem prywatnym, choć w pierwszych latach po zakończeniu działań wojennych nie było to tak bardzo dostrzegane. Zarządzenie Ministra Oświaty z dnia 19 marca 1945r. (Nr II-Śr. 2220/45) o nadawaniu prywatnym szkołom średnim ogólnokształcącym, zakładom kształcenia nauczycieli oraz szkołom zawodowym typu zasadniczego uprawnień szkół państwowych, Dz. Urz. Min. Ośw. 1945/Nr1/poz. 3.

${ }^{28}$ AMO, Gabinet Ministra, Wydział Prezydialny, 4/27, (za:), S. Mauersberg, op.cit., s. 129-30.

${ }^{29}$ E. Kryńska, S. Mauersberg, Indoktrynacja mtodzieży szkolnej w Polsce w latach 1945-1956, Białystok 2003, s. $17-18$.
} 
Władze komunistyczne wyszukiwały rozmaitych pretekstów do zamykania szkół katolickich, a jeżeli ich nie znajdowały, to po prostu powiadamiały dyrekcję danej szkoły, że „nie została ona przewidziana w sieci szkolnej na najbliższy rok szkolny”30. Innym sposobem było pozbawianie określonej szkoły $\mathrm{z}$ roku na rok prawa naboru uczniów do klasy pierwszej, co prowadziło do powolnego wygasania szkoły, a jej lokale i sprzęt, będące własnością zakonu, rekwirowano zazwyczaj na rzecz szkolnictwa państwowego ${ }^{31}$.

Narastająca sytuacja polityczna w Polsce spowodowała, że w roku 1948 został zamknięty szereg szkół katolickich, a te, które zostały, były przejmowane przez państwo. Jak wyraża list Episkopatu do prezydenta B. Bieruta, sytuacja taka ,jest sprzeczna nie tylko $\mathrm{z}$ wolnością sumienia i wyznania, ale jest to wręcz ingerowanie w wewnętrzne życie Kościoła. Do wyraźnych i podstawowych praw Kościoła należy możność prowadzenia szkół katolickich, do których uczęszczałyby dzieci rodziców katolickich, bowiem znakomita większość społeczeństwa polskiego są to wierzący katolicy. Laicyzacja całego szkolnictwa w Polsce, [...]. jest pogwałceniem swobody religijnej, zagwarantowanej w Konstytucji"32.

Prywatne szkoły średnie ogólnokształcące znacznie ograniczono też w związku z wprowadzeniem 11-latek w roku szkolnym 1948/49 i było to od strony ideologicznej podyktowane m.in. przez Teofila Wojeńskiego, który w referacie wygłoszonym podczas zjazdu kuratorów w sierpniu 1947 wypowiedział się przeciwko istnieniu szkół stanowiących własność prywatną osób i klasztorów. Zdaniem Wojeńskiego „szkoły te zakładane są albo z chęci zysku, albo stanowią narzędzie walki Kościoła o dusze młodego pokolenia, są światopoglądowo obce i narażają młodzież na konflikty $\mathbf{z}$ otaczającą ich rzeczywistością społeczną". Wojeński szkoły te zalecał likwidować drogą zahamowania dalszego ich rozwoju, a następnie upaństwawiać te, które, zgadzały się z ówczesnym oficjalnym duchem oświatowym, a zarazem były niezbędne ze względu na sieć szkolną i potrzeby społeczne ${ }^{33}$.

W latach 1944-1948 w Polsce istniały więc zarówno szkoły średnie ogólnokształcące państwowe, jak i prywatne. Szkoły państwowe miały niewielką przewagę liczbową. Do roku 1950 natomiast nastąpiło wyraźne ograniczenie zasięgu oddziaływania szkolnictwa prywatnego. Akcja upaństwowienia szkolnictwa średniego po roku 1948 wiązała się oczywiście z podjętą w szkolnictwie ofensywą ideologiczną, zmierzającą do ujednolicenia pracy dydaktyczno-wychowawczej szkół i tworzenia wspólnej platformy ideowej. W tej sytuacji szkoły prywatne, a zwłaszcza te, które prowadzone były przez związki religijne, nie mogły dłużej funkcjonować, gdyż nie odpowiadały wymaganiom ówczesnych władz oświatowych ${ }^{34}$.

\footnotetext{
${ }^{30}$ Listy kardynałów A. Hlonda i A. Sapiehy z 24 czerwca 1948r. do prezydenta B. Biureta oraz Bpa Z. Choromańskiego, sekretarza Episkopatu, z 23 sierpnia 1948 r. do Ministerstwa Oświaty, (za:) P. Raina, Kościót w PRL. Kościót katolicki a państwo w świetle dokumentów 1945-1989, t. 1: Lata 1945-1959, Poznań 1994, s. 127, 128, 130, 131.

${ }^{31}$ Ibidem.

${ }^{32}$ List Episkopatu Polski do Prezydenta B. Biureta w sprawie sytuacji Kościoła w Polsce (dn. 22 grudnia 1948 r.), (w:) P. Raina, op.cit., s. 137

${ }^{33}$ T. Wojeński, Zagadnienie szkolnictwa prywatnego, „Nowa Szkoła” 1947/48, $\mathrm{nr} 2 / 3$.

${ }^{34}$ A. Meissner, Ksztaltowanie się sieci średniego szkolnictwa ogólnoksztatcącego w Polsce w latach 1944-1950, „Rocznik Komisji Nauk Pedagogicznych” t. XXXII-1984, s. 64-65.
} 
Materiały statystyczne opublikowane przez Ministerstwo Oświaty w latach 1945-1948 przedstawiają podział szkół średnich ogólnokształcących na szkoły państwowe i szkoły prywatne (tabela). Na podstawie opublikowanych statystyk szkolnych nie można w pełni prześledzić procesu upaństwowienia szkolnictwa średniego. Można natomiast sądzić, że następowało wyraźne ograniczanie zasięgu oddziaływania szkolnictwa prywatnego w Polsce ${ }^{35}$.

Tabela. Średnie szkoły ogólnokształcące państwowe i prywatne w Polsce w latach $1945 / 46-1948 / 49^{36}$. Dane szacunkowe

\begin{tabular}{|c|c|c|c|c|c|}
\hline \multirow{2}{*}{ Lata } & \multirow{2}{*}{$\begin{array}{c}\text { Ogólna liczba } \\
\text { szkół }\end{array}$} & państwowych & $\%$ & prywatnych & $\%$ \\
\hline $1937 / 1938$ & 777 & 308 & 39,6 & 469 & 60,4 \\
$1945 / 1946$ & 705 & 384 & 54,5 & 321 & 45,5 \\
$1946 / 1947$ & 758 & 442 & 58,3 & 316 & 41,7 \\
$1947 / 1948$ & 742 & 469 & 63,2 & 273 & 36,8 \\
$1948 / 1949$ & 823 & 617 & 75,0 & 206 & 25,0 \\
\hline
\end{tabular}

\section{Eliminacja edukacji religijnej ze szkół średnich ogólnoksztalcących w dobie odbudowy szkolnictwa w Polsce powojennej}

Polska władza ludowa, od początku swego istnienia dążyła do wprowadzenia i egzekwowania zasady rozdziału Kościoła od państwa. Deklaracje te komuniści polscy określili już w ogólnych zarysach w Deklaracji Programowej PPR pt. „O co walczymy?” z listopada 1943 r., potwierdzając swoje stanowisko w Manifeście PKWN z lipca 1944 r.

W kontekście deklaracji rozpoczęła się obudowa szkolnictwa polskiego, której podstawowym założeniem była zmiana ustroju szkolnego: jego podstaw organizacyjnych, a przede wszystkim dotychczasowej ideologii wychowawczej. Uznając poniekąd dziedzictwo i dorobek przeszłości polskiej oświaty, władze rozpoczęły walkę o nowe oblicze ideowe szkoły.

Jednym z zasadniczych elementów tej walki stała się kwestia nauczania religii oraz wychowania religijnego $\mathrm{w}$ szkołach $\mathrm{i}$ poza nimi. W nowej sytuacji politycznej było rzeczą oczywistą, że problematyka ta, opierająca się dotąd na przedwojennych uregulowaniach prawnych, stanie się płaszczyzną walki władzy ludowej i Kościoła, walki, której ceną było wychowanie młodzieży. Władzy ludowej chodziło o zmianę tego wychowania z państwowego i narodowego oraz religijnego na wychowanie świeckie, a zmian tych dokonywano głównie na gruncie szkoły.

\footnotetext{
${ }^{35}$ Ibidem, s.64

${ }^{36}$ Szkolnictwo w liczbach 1945/46, Warszawa 1946, s. 26; Przyczynki statystyczne, z. 1, Warszawa 1947, s. 36; Szkolnictwo w roku szkolnym 1947/1948 w liczbach tymczasowych, „Rocznik Statystyczny” 1947, s. 160 i 1949, s. 206; Statystyka szkolnictwa w latach 1945/46 i 1946/47, GUS, Warszawa 1948, Seria D, z. 7 , s. $51-59$.
} 
Nauka religii w powojennej Polsce stawała się przedmiotem coraz bardziej intensywnej walki władz państwowych i partyjnych $\mathrm{z}$ katolickim społeczeństwem, walki, która wyrażana była w bardzo różnej formie.

Po zakończeniu działań wojennych, kiedy szkoły wszystkich szczebli powstawały żywiołowo, posługiwano się w nauczaniu przedwojennymi rozkładami lekcji, w których pierwsze miejsce zajmowała religia realizowana w wymiarze dwóch lekcji tygodniowo w każdej klasie zarówno w szkole powszechnej, jak i w średniej. Religii uczyli - podobnie jak przed wojną - duchowni, katecheci lub nauczyciele przedmiotów świeckich, którzy obdarzeni zostali przez Kościół tzw. misją kanoniczną (missio canonica).

Również otwieraniu nowych szkół i wznawianiu w nich zajęć lekcyjnych towarzyszyły tradycyjne obrzędy religijne. Ówczesne władze państwowe zdawały sobie $\mathrm{z}$ tego sprawę. Wszelkie jednak próby przeciwdziałania tym praktykom, zabiegi w celu ograniczenia obecności Kościoła w szkole, spotykały się z ostrą krytyką ze strony społeczeństwa, kleru, nauczycieli, rodziców i młodzieży ${ }^{37}$.

Z czasem władze komunistyczne państwa polskiego przystąpiły do ograniczania edukacji religijnej młodzieży. Czyniły to jednak dość sukcesywnie, ponieważ miały świadomość silnego przywiązania społeczeństwa polskiego do nauczania religii w szkołach oraz do wychowania chrześcijańskiego w ogóle.

Jednym z pierwszych zagadnień w kwestii ograniczania wpływu Kościoła i nauki religii na dzieci i młodzież szkolną było uzależnienie pobierania nauki religii od woli i życzeń rodziców, co faktycznie czyniło religię przedmiotem nadobowiązkowym. Taka postawa była sprzeczna z postanowieniami Konstytucji marcowej z 1921 r., której podstawowe założenia miały obowiązywać do czasu uchwalenia nowej konstytucji ${ }^{38}$.

Ówczesny minister oświaty, Stanisław Skrzeszewski, podczas Zjazdu łódzkiego w czerwcu 1945 stwierdzil, że: „,stosunek do nauczania religii nie ulegnie zmianie; zapewniamy, w myśl wytycznych naszego Rządu, całkowitą swobodę nauczania religii w szkole oraz praktyk religijnych; równocześnie, w myśl podstawowych zasad demokracji, nie uszczuplimy swobody sumienia, nie będziemy stosowali przymusu w kwestiach, dotyczących wewnętrznego życia jednostki”39. Takiej samej odpowiedzi udzielił on wcześniej na list zaniepokojonego abpa A. Sapiehy skierowany do Ministerstwa Oświaty, w którym arcybiskup przestrzega przed fatalną pomyłką, jaką byłoby stworzenie szkoły bezwyznaniowej i materialistycznej. W sprawach odnoszących się do nauczania religii pisał: „Na pierwszym miejscu ma być ustanowiona fakultatywność nauki religii, jej nieobowiązkowość i zależność od życzenia rodziców. Ta dowolność sprzeciwia się art. XIII Konkordatu $^{40}$, zawartego ze Stolicą Apostolską, który dotychczas obowiązuje. Nadto

\footnotetext{
${ }^{37}$ H. Konopna, Religia w szkolach Polski Ludowej. Sprawa nauczania religii w polityce państwa (1944-1961), Białystok 1995, s. 11.

${ }^{38}$ Artykuł 120 Konstytucji z 17 marca 1921r. mówił, że „W każdym zakładzie naukowym, którego program obejmuje kształcenie młodzieży poniżej lat 18, utrzymywanym w całości lub części przez państwo lub ciała samorządowe, jest nauka religii dla wszystkich uczniów obowiązkową", Dziennik Ustaw RP 1921/Nr 44/poz. 267.

${ }^{39}$ Ogólnopolski Zjazd Oświatowy w Lodzi 18-22 czerwca 1945 roku, Warszawa 1945, s. 59.

${ }^{40}$ Konkordat między Stolicą Apostolską a Rzeczpospolitą Polską z dnia 10 lutego 1925 r., Dz. U. RP 1925/Nr72/ poz. 501 .
} 
sprzeciwia się postanowieniom Konstytucji Polskiej, także i tej z dnia 17 marca 1921 r. $^{41}$ art. 120, którą to Konstytucję Tymczasowy Rząd dzisiejszy uważa za obowiązującą. Wreszcie nie zgadza się z oświadczeniem rzeczywistym premiera [Edwarda Osóbki-Morawskiego], złożonym wobec przedstawicieli prasy zagranicznej w Moskwie, iż „Rząd tymczasowy nie tylko nie stawia żadnych przeszkód Kościołowi katolickiemu, ale wprost przeciwnie, uczynił wszystko, by zapewnić Kościołowi w Polsce odpowiednie warunki”" („Dziennik Polski” 1945/Nr83, s. 3). Nie tylko my Biskupi, ale ogromna większość rodziców o różnych zapatrywaniach politycznych jest temu projektowi wprost przeciwna i żąda, by tak podstawowy przedmiot, jak nauka religii nie był traktowany jako zbędny i mniej wartościowy"42.

Problem świeckości polskiej szkoły, znacznie szerszy, niż sprawa nauczania religii, był różnie widziany przez poszczególne partie. Ich przedstawiciele nie wyrazili wprawdzie otwartego stanowiska w sprawie nauczania religii, niemniej zarówno Polska Partia Socjalistyczna, jak i Stronnictwo Ludowe, widziały laicyzację szkoły polskiej przez usunięcie religii z programów nauczania. Podczas Zjazdu łódzkiego przedstawiciel CKW SL - Wilhelm Garncarczyk powiedział, „iż my, ludowcy, stoimy całkowicie na gruncie szkoły świeckiej i nie widzimy potrzeby nauczania w szkole religii jako przedmiotu obowiązkowego. Do tego mamy kościoły, do których dziatwę naszą posyłamy"43. Zdanie to podzielała PPS, która widziała konieczność „oddzielenia religii od państwa i szkoły”44. PLS w tej kwestii zajęło stanowisko bardziej ostrożne, ponieważ w szeregach tej partii było wielu katolików, stąd partia ta nie była zainteresowana laicyzacją szkoły polskiej ${ }^{45}$.

Od dnia 25 czerwca 1945 r. nowy minister oświaty w Tymczasowym Rządzie Jedności Narodowej, członek ZG ZNP i PSL - Czesław Wycech, nie zmienił, wbrew oczekiwaniom, kierunku działań władz oświatowych w zakresie nauczania religii i praktyk religijnych w szkołach.

Zagadnienie nauczania religii w szkołach, tzn. jej ograniczenia, wymagało rozwiązania co najmniej dwóch problemów prawnych, a mianowicie ustaleń wynikających $\mathrm{z}$ konkordatu oraz postanowień Konstytucji marcowej. Uchwała TRJN z dnia 12 września 1945 r. o wygaśnięciu konkordatu rozwiązywała problem pierwszy. W przypadku natomiast problemu drugiego, Rada Ministrów powołała się na opinię Komisji Prawniczej przy Ministerstwie Sprawiedliwości, przygotowanej w sierpniu $1945 \mathrm{r}^{46} \mathrm{~W}$ wyniku rozstrzygnięć Komisji Prawniczej, minister oświaty - Cz. Wycech wydał w dniu 13 września 1945 r. okólnik regulujący naukę szkolną religii ${ }^{47}$, w którym „,zwalnia dzieci od przymu-

\footnotetext{
${ }^{41}$ Konstytucja RP z 17 marca 1921 r., Dz. U. RP 1921/Nr44/poz. 267.

${ }^{42}$ AAN, MO, sygn. 411, List ks. abp. A. S. Sapiehy z dn. 5 czerwca 1945 r. do Min. S. Skrzeszewskiego, 17 lat nauczania religii w Polsce Ludowej. Wybór dokumentów, (opr.) Hanna Konopna, Białystok 1998, s. 21-22.

${ }^{43}$ Ogólnopolski Zjazd Oświatowy..., s. 114.

44 „Barykada Wolności”, Nr1, 30.06.1945 r.

${ }^{45}$ J. Jakubowski, Polityka oświatowa PPR 1944-1948, Warszawa 1975, s. 193.

${ }^{46}$ Dwie opinie prawne $z$ dziedziny stosunków Kościola $i$ państwa, „Demokratyczny Przegląd Prawniczy" 1945/Nr 1; K. H. Jabłoński, Aspekty prawne nauczania religii w Polsce Ludowej, „Zeszyty Naukowe Uniwersytetu Jagiellońskiego" 1983/z. 9, s. 68, (za:) H. Konopna, op.cit., s. 16.

${ }^{47}$ Okólnik nr $50 \mathrm{z}$ dn. 13 września 1945r. w sprawie nauki szkolnej religii, Dziennik Urzędowy Ministerstwa Oświaty $1945 / \mathrm{Nr}$ 4/poz.189.
} 
su pobierania nauki religii w szkole", ponieważ artykuł 111 Konstytucji marcowej poręczał wszystkim obywatelom wolność sumienia i wyznania (chociaż artykuł 120 tejże Konstytucji mówił o obowiązkowym charakterze szkolnej nauki religii). W związku z okólnikiem minister zarządził, iż: 1) nauka religii jest w szkołach publicznych obowiązkowa dla wszystkich uczniów, należących do uznanych przez państwo wyznań; 2) uczniowie, których rodzice zadeklarują, że nie życzą sobie, aby ich dzieci pobierały naukę religii, sq̨ od tej nauki zwalniane; 3) uczniom tym nie wystawia się na świadectwie stopni $\mathrm{z}$ nauki religii ${ }^{48}$.

Okólnik z 13 września 1945 r. stworzył nową podstawę prawną, w której rozporządzenie Ministra WRiOP z 9 grudnia 1926 r. $^{49}$ oraz „Okólnik Bartla" z 1927 r. faktycznie przestały obowiązywać. Okólnik ten znalazł poparcie partii rządzących PPR i PPS. Egzekwowanie wykonywania okólnika z 13 września 1945 r. nie sprawiało większego kłopotu. Realizowano go m.in. przez wykreślenie w czerwcu 1945 r. religii jako przedmiotu egzaminu maturalnego w liceum pedagogicznym, usunięcie nauki religii ze szkół dla dorosłych, zmniejszenie wymiaru godzin tego przedmiotu w szkołach zawodowych, przetrzymywanie w cenzurze podręczników do nauki religii ${ }^{51}$.

Takie poczynania Ministerstwa Oświaty wywołały reakcję Kościoła, który w sytuacji coraz silniej narastającej ofensywy ideologicznej ze strony władz, rozpoczął działania, mające umocnić jego pozycję w państwie. W memoriale z 15 września 1946 r., polemizował m.in. ze stanowiskiem ministra oświaty - Cz. Wycecha, zwracając uwagę na to, że okólnik ministra spycha religię do rzędu przedmiotów nadobowiązkowych, bo jak pogodzić rzekomą jej obowiązkowość z możliwością wydawania prawomocnych świadectw szkolnych bez oceny z nauki religii. Zdaniem Episkopatu obniżenie rangi szkolnej nauki religii pomniejszało jej wartość w opinii uczniów i społeczeństwa, a ponadto kłóciło się z polską tradycją, która wychowanie religijne uważała jako pierwszy i najważniejszy obowiązek szkolny ${ }^{52}$.

Po uchwaleniu Małej Konstytucji 19 lutego 1947 r. władze oświatowe za miarodajną wykładnię kwestii nauczania religii przyjęły „Uwagi o niektórych zagadnieniach ustaw konstytucyjnych z 4 i 19 lutego 1947 roku, $^{\text {,53 }}$. Mała Konstytucja nie tylko nie znosiła Konstytucji marcowej, ani Manifestu Lipcowego PKWN, ale wręcz na wstępie stwierdzała, że Konstytucję tę nadaje się w oparciu o podstawowe założenia tych aktów. Ponieważ żaden $\mathrm{z}$ artykułów Konstytucji marcowej dotyczących szkolnictwa i nauczania nie został w nowej Konstytucji powołany, uznano, że w tym zakresie ustawodawca nie podlega żadnym poprzednim ograniczeniom Konstytucji ${ }^{54}$. Również konkordat, stanowiący

\footnotetext{
${ }^{48}$ E. Kryńska, S. Mauersberg, op.cit., Białystok 2003, s. 15.

${ }^{49}$ Rozporządzenie Ministra WRiOP z dn. 9 grudnia 1926 r. o nauce szkolnej religii katolickiej, Dziennik Ustaw RP, 1926/Nr1/poz.9.

${ }^{50}$ Okólnik Ministra WRiOP do Kuratoriów Okręgów Szkolnych w sprawie nauczania religii w publicznych szkołach powszechnych, Dziennik Ustaw RP, 1927/Nr2/poz. 32.

${ }^{51}$ P. Raina, op.cit., s. 33-41.

${ }^{52}$ Ibidem, s. 36.

${ }^{53}$ Uwagi o niektórych zagadnieniach ustaw konstytucyjnych z 4 i 19 lutego 1947 r., „Demokratyczny Przegląd Prawniczy" 1947/Nr 3.

${ }^{54}$ AAN MO, sygn. 414, Zestawienie przepisów o nauce religii rzymskokatolickiej za okres przed uchwaleniem małej Konstytucji z 1947 r., (za:) H. Konopna, op.cit., s. 24.
} 
drugą podstawę prawną nauczania religii w szkołach, przestał obowiązywać zgodnie z deklaracją rządu z 1945 r., Ministerstwo Oświaty przyjęło interpretację, że większość rozporządzeń, okólników itp. dotyczących nauczania tego przedmiotu, powołujących się na Konstytucję marcową i na konkordat, traci moc, dając rządowi pełną swobodę w nowym regulowaniu tej problematyki ${ }^{55}$.

Po zwycięstwie wyborczym Bloku Stronnictw Demokratycznych w styczniu 1947 r., ministrem oświaty został ponownie Stanisław Skrzeszewski. Po wyborach też, w zmieniającej się sytuacji politycznej, nowego wydźwięku nabrały sprawy nauczania religii i propagowanie treści religijnych w szkole. Środowisko katolickie reprezentowali w Sejmie Ustawodawczym: Jan Frankowski, Aleksander Bocheński i Witold Bieńkowski. Klub Katolicko-Społeczny był wobec komunistów dość słabą opozycją. Jednak grupa ta przejawiała znaczną aktywność polityczną. Bezpośrednie starcie przedstawicieli odmiennych kierunków ideowo-wychowawczych miało miejsce kilkakrotnie w Sejmie. M.in. poseł katolicki Witold Bieńkowski podkreślał, iż polityka oświatowa państwa polskiego jest szkodliwa dla idei łączenia wszystkich obywateli w słuźbie państwa, gdyż np. tendencje upaństwowienia wszystkich szkół są sprzeczne z interesami katolików, którzy chcą posiadać własne szkoły wyznaniowe. Podkreślał on, że katolicy, dla których wychowanie należy do rodziny, państwa i Kościoła, nie zrezygnują z wpływów wychowawczych Kościoła. Witold Bieńkowski domagał się uznania programów szkolnych z zasadami dogmatyki i etyki katolickiej oraz swobody działalności w szkole religijnej organizacji młodzieży ${ }^{56}$. Wystappienie to znalazło poparcie w klubie poselskim PSL, w którego imieniu występował poseł Wincenty Bryja. Oświadczył on, że jego stronnictwo będzie głosowało przeciw budżetowi Ministerstwa Oświaty, ponieważ „obecny minister oświaty w swoim programie i działalności idzie wyraźnie w kierunku upartyjnienia całokształtu wychowania narodowego"57.

Taki bieg wydarzeń zmusił Kościół katolicki do rozpoczęcia działań, które miały umocnić jego pozycję w państwie. Episkopat złożył premierowi w marcu 1947 r. memoriał w sprawie postulatów konstytucyjnych, w którym domagał się, aby Konstytucja nadała państwu polskiemu charakter chrześcijański i wyznaniowy oraz zapewniła szerokie uprawnienia Kościołowi, obejmujące m.in. prowadzenie zakładów wychowawczych, prowadzenie szkół, a także nauczanie religii we wszystkich szkołach publicznych i prywatnych ${ }^{58}$.

Obok Kościoła również Stronnictwo Pracy propagowało wychowanie wspierające się na moralności i filozofii chrześcijańskiej. Podkreślając idee humanizmu i chrystianizmu, Stronnictwo Pracy zaznaczało potrzebę udziału Kościoła w pracy wychowawczej, wypowiadając się jednocześnie za autonomią i niezależnością szkolnictwa od władz politycznych i administracyjnych ${ }^{59}$.

\footnotetext{
${ }^{55}$ H. Konopna, Podstawowe uregulowania prawne nauczania religii w powojennej Polsce (1944-1956), w: Białostockie Teki Historyczne, t. 1, Białystok 1995, s. 103-129.

${ }^{56}$ Wielka mowa posta Bieńkowskiego, „Słowo Powszechne” 21.06.1947 r.

${ }^{57}$ Sprawozdanie stenograficzne z posiedzenia Sejmu w dniu 20 czerwca 1947, łam 38, (za:) S. Mauersberg, op.cit., s. 197.

${ }^{58}$ N. Kołomejczyk, B. Syzdek, Polska w latach 1944-1949, Warszawa 1971, s. 183-185, (za:) S. Mauersberg, op.cit., s. 196.

${ }^{59}$ Tezy programowe Stronnictwa Pracy, Warszawa 1946, s.13, 14, (za:) S. Mauersberg, op.cit., s. $196-197$.
} 
Atmosfera wzajemnej nieufności zagęszczała się jesienią $1947 \mathrm{r}$. Jednym z narzędzi polityki władz państwowych $\mathrm{w}$ sprawie nauczania religii w szkołach było wydawanie rozporządzeń i przepisów wykonawczych w trybie administracyjnym, rezygnując coraz częściej z ogłaszania ich w Dzienniku Ustaw czy Dzienniku Urzędowym Ministerstwa Oświaty. Jesienią 1947 r. minister oświaty rozesłał do kuratoriów okręgów szkolnych projekt rozporządzenia w sprawie nauki religii w szkołach. Nakazał w nim przeciwstawianiu się przerostom klerykalizmu $i$ bigoterii, wykorzystywaniu przez prefektów nauki religii do innych celów. Podkreślał też konieczność dopuszczania do użytku młodzieży tylko tych podręczników do nauki religii, które posiadały aprobatę Ministerstwa Oświaty ${ }^{60}$.

Do kolejnego incydentu doszło podczas obrad sejmowej Komisji Skarbowo-Budżetowej, a następnie na forum Sejmu podczas sesji budżetowej w grudniu 1947 r. w związku z odwołaniem przez władze szkolne niektórych nauczycieli religii, a szczególnie zakonników i zakonnic za, jak to określono - wykorzystywanie lekcji religii do uprawiania propagandy antysocjalistycznej.

W kontekście powyższych wydarzeń, 23 maja 1948 r. (w przededniu Zjazdu Poznańskiego) odczytano $\mathrm{z}$ ambon kościelnych list pasterski Episkopatu Polski skierowany do rodziców i młodzieży. W liście tym ostrzegano przed niebezpieczeństwem zmaterializowania życia przez odstępowanie od wiary. Nawoływano do kształtowania religijnego oraz uprawiania praktyk religijnych, utrzymywania żywej wiary w pokrewieństwo człowieka z Bogiem. Zachęcano do gruntownych studiów, które pozwolą zrozumieć, że materia to nie wszystko i że nie tylko chlebem człowiek żyje ${ }^{61}$.

Poruszane w liście sprawy światopoglądowe były tylko pretekstem, gdyż w rzeczywistości list Episkopatu i akcja katolików w Sejmie były przejawami walki Kościoła przeciwko polityce oświatowej nowych władz szkolnych działających pod kierunkiem KC PPR. Kościół zdawał sobie sprawę, że celem polityki jest wychowanie socjalistyczne młodzieży, dlatego posługiwał się różnymi argumentami dla jego zwalczania ${ }^{62}$.

Do roku szkolnego 1947/48 włącznie religii nauczano we wszystkich szkołach. Co prawda zakres tego nauczania w wielu przypadkach był ograniczony, jednak zajęcia odbywały się. Działo się tak dlatego, że religia jako obowiązkowy przedmiot nauczania, znajdowała się w programach szkolnych, a w planach godzin nadal była na pierwszym miejscu ${ }^{63}$.

Pierwsze lata powojenne w polskim szkolnictwie wyraźnie wskazują, że rozpoczął się proces systematycznego wypierania nauki religii i praktyk religijnych ze szkół wszystkich szczebli, również ze szkoły średniej ogólnokształcącej. Zmiany te, motywowane obłudnie koniecznością przestrzegania zasady wolności sumienia i wyznania, prowadziły do laicyzacji szkolnictwa. Owe skuteczne wypieranie Kościoła ze szkół, a tym samym z pola kształtowania młodego pokolenia, miało służyć tworzeniu w przyszłości nowego, socjalistycznego społeczeństwa.

\footnotetext{
${ }^{60}$ AAN MO, sygn. 414, Projekt w sprawie szkolnej nauki religii do Kuratoriów Okręgów Szkolnych, (za:) H. Konopna, op.cit., s. 31 .

${ }^{61}$ List pasterski: Ukochani Rodzice - Droga Młodzieży Polska!, „Tygodnik Warszawski, Nr 23 z dn. 6 VI 1947, (za:) S. Mauersberg, op.cit., s. 198.

${ }^{62}$ Ibidem, s. 199.

${ }^{63}$ H. Konopna, op.cit., s. 33.
} 


\title{
Controversy Over the Constitutional, Organizational and Program Structure of General Secondary Schools in Poland in the Years 1944-1948
}

\begin{abstract}
Summary
A new form of government of the Polish state was combined with its rather intensive influence on the character of the educational system, including general secondary schools. That time is distinguished by numerous controversies, which then appeared in various social circles, political parties, and referred to the constitutional and organizational structure as well as the program structure of this school level. In the first years the controversies were more of an evolutionary character, as at that time discussion and exchange of opinions concerning differing standpoints and concepts for the Polish route to socialism were still possible. After 1948 there was no more room for discussion; the decisions about this sphere were also made by one group - the people related to the communist party (Pol. abbr. PZPR).

Already right after the cessation of war activities, the tendencies leading to the centralization of education management were noticeable, and consequently, ever more intense influence of the government of the working classes (lub the people's government) on the functioning of schools, but, above all, on the teaching content. The process of centralization was linked with the so-called democratization process of school i.e., the question, of which the ruling communists made their priority. A consequence of democratization of the general secondary school and rendering it a tool for the manufacture of future citizens - devoted to and subjected to the government of the working classes - was the aspiration for closing private general secondary schools, and also the expulsion of religion from school. Such changes, falsely justified by the necessity to observe the principle of freedom of conscience and confession, led to the secularization of the school system. The discussed expulsion of the Church from schools, and at the same time from the sphere of educating a young generation, was supposed to serve the formation of a new socialist society in the future.
\end{abstract}

